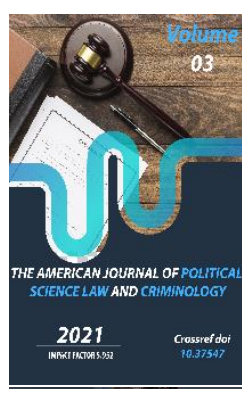

\title{
Theoretical Aspects Of Foreign Policy Research: Case Study Relationships Of South Korea And Uzbekistan
}

\author{
Gulbakhor Zokhidzhon Kizi Khamrakulova \\ Tashkent State University Of Oriental Studies, Uzbekistan
}

Journal Website: http://usajournalshub.c om/index,php/tajpslc

Copyright: Original content from this work may be used under the terms of the creative commons attributes 4.0 licence.

\section{ABSTRACT}

This paper analyses foreign policy research with theories of international relations study such as realism and liberalism. Then work continues applying theories of realism and liberalism with case study. As a case study have been chosen bilateral relations of South Korea with Uzbekistan and there is chosen Complex interdependence theory for that. In that case, complex interdependence more suitable to define cooperation of two countries such as Uzbekistan and South Korea. One of the arguments is that relations of South Korea and Uzbekistan by three conditions which are absence of force, lack of hierarchy and contact of multiple channels. From these criteria we can see that there is no role of power or force between two countries relations, the most accent has made in different kind of cooperation between them which is appropriate with multiple channels are playing significant role in this condition.

\section{KEYWORDS}

Realism, liberalism, complex interdependence, foreign policy, diplomatic relations, South Korea, Uzbekistan. 


\section{INTRODUCTION}

In this research work we are going to analyze and describe foreign policy and most noticeable realism and liberalism approaches which can be most suitable to identifying and explaining relations of South Korea and Uzbekistan.

Realizing their foreign policy functions, each state pursues a certain policy outside its country in the international arena. The foreign policy of the state is a set of actions aimed at establishing and maintaining relations with the international community, protecting its own interests and expanding its influence on other subjects of international relations. The foreign policy of the state relates to the internal and in each specific situation the priority of domestic or foreign policy is determined separately, although usually domestic policy is a priority and it is she who determines foreign policy, since foreign policy is carried out for the sake of internal interests.

The main determinative force of foreign policy activity is national or state interest. But the very concept of national interest is permeated with value norms and ideological content. This is especially true of misunderstood and misconstrued national interests. In the formulation of both categories of interests and in the formation of a foreign policy strategy designed to implement them, the system of value orientations, attitudes, principles and beliefs of statesmen is of no small importancetheir perception of the world around them and assessment of their country's place among other states that make up the world community.

In foreign policy researches there are theories which can describe nature of international relations, especially bilateral relations of states. In international relations there are realism and liberalism approaches that are most powerful contrast theories and one of them can be best explaining of current our case study.

\section{Theoretical basis of foreign policy research}

Foreign policy that regulates relations between states and peoples in the international arena. The foreign policy of this or that country is a concrete practical implementation by the relevant (foreign policy) department of the basic principles of the international policy of the state. Foreign policy goals reflect national interests. Realizing them, the state carries out foreign policy activities. The state policy in the international arena is formed under the influence of both external and especially internal factors. To date, foreign policy analysis has become an important part of the theory. Most analysts believe it to be and independent branch of theoretical approaches to the study of states, international relations and world politics.

Foreign policy is based on the economic, demographic, military, scientific, technical, cultural potential of the state; their combination determines the opportunities for foreign policy activities of the state in certain areas, creates a hierarchy of priorities in setting and implementing the goals of foreign policy. The form of the traditional implementation of foreign policy is the establishment of diplomatic relations between states, the opening of representative offices of states in international organizations or membership in them. The existence of stable channels of communication with foreign partners allows 
the state to diversify the combination of means and methods of foreign policy activity, to carry out regular exchange of information, visits at different levels, to conclude contracts, on various issues.

The foreign policy of the state is determined by a multitude of determinants, including the level of socio-political, socio-economic development, the geographic location of the country, its national and historical traditions, the goals and requirements of securing sovereignty, security, etc.

Foreign policy is the general course of the state in international affairs. It regulates the relations of this state with other states and peoples in accordance with its principles and objectives, which are implemented in various ways and methods. In this case, it combines national interests and values with common human interests and values, especially in matters of security, cooperation and peace consolidation, in solving global international problems arising in the path of social progress.

Formation of foreign policy occurs as the objective requirements of a given society or state mature, to enter definite relations with the outside world, that is, with other societies or states. Therefore, it appears later than domestic policy.

There are many theories of foreign policy, which explain its main goals and tasks, essence and functions in different ways.

\section{Realism in international relations}

Realism is one of the dominant theoretical approaches in international relations. It gives most potent description of nature of state and state as subject of international arena, national interest, rationalism, sovereignty. Advocates of realist school argues that international system is anarchy, where lack of central government. In contrast this in domestic societies is hierarchy. "Leviathan" Thomas Hobbes, where we can find good explanation of state and hierarchy system in domestic politics. There says that about human nature and its egoistic actions, where mentioned principle man to man as wolf. So that people do not destroy each other, they need conclude social contract and give power to someone. In this point someone is from point of view Hobbes is monster Leviathan, it's just symbolic sketch, in reality someone is government which is humanmade above staying institution. People give to government part of their interests, rights, power and start to control above them by legal, legitimated lows. On basis of this appears government institution it maybe, democratic or monarchic, but main point is that this power government rule and control whole state above people by legal tools. That is why in realists say that domestic policy is hierarchic. On the other hand, we can see that international system there is no above staying intuitions or actors which can enforce a system of law. Because all subjects or state in international system are in a same level and they can not enforce, control above each other, because there is sovereignty of state are playing main role.

Sovereignty is most important norm that is an opportunity for the state to freely and independently implement its foreign and domestic policies. Sovereignty presupposes the independence of the state in the foreign policy sphere (in the field of international relations) and the supremacy, indisputability of its decisions in internal affairs. Sovereignty as a concept of international law has three main aspects: external, internal and territorial. The 
external aspect of sovereignty is the right of the state to freely determine its relations with other states or subjects of international law, without restriction or control on the part of another state. This aspect of sovereignty is also known as independence. The internal aspect of sovereignty is the exclusive right or competence of the state to determine the nature of its own institutions, to enact laws at its own discretion and enforce them. The territorial aspect of sovereignty is the power that the state enjoys with respect to all persons and things located on, under or above its territory. In this case in bilateral relations of South Korea and Uzbekistan, they are realizing their cooperation by respecting of each other's sovereignty. For example, realizing of energy security interests, South Korea does not intervene into territory of Uzbekistan under the name of non-democratic actions or export own ideology, interference in state affairs. Instead of this they respect and follow norm of sovereignty. That is why as a new democratic independent state prefer cooperation with South Korea, during 29 years of their relations there was not traced up and downs.

In international relations states acting as subjects of this system and they are objectively exist, namely they have objective, material, physical expressions. So, the objective side of the state is subject calculation. The subjective side of the government is rational analysis of reflection. From point view realists to account of subjective and objective sides of state can build a model of so-called national interests. The concept of national interest and the content of foreign policy is determined by the fact that each national state in the international arena seeks to realize its interest. And although the foreign policy of most states in different epochs was largely determined by what is now called national interest, the very notion of "national interest" entered the scientific circulation only in the first half of the twentieth century. Among the founders of the development of this term, American scientists Reinhold Niebuhr, Hans Morgenthau. The concept of national interest, despite its sufficient elaboration, is still a category of abstract and subjective, since its parameters are determined by the picture of the world and the value system that dominates in a certain society and state. There appear various interests of states such as economic, environmental, humanitarian and so on. Realists argues that national interest are basic category that is based on calculation. Before the choosing or accounting as national interest there state make clear calculation, analyzing. For instance, for South Korea as national interest energy diplomacy in Uzbekistan. There Uzbekistan is alternative energy exporter country, but after some period it would be main partner in this sphere, because it depends on situation in energy resource rich countries such Arabic countries and Iran. To account worst situations in these areas, South Korea choose Central Asian countries as energy exporter partner. We know that, nowadays USA and Iran's relations are in stage of down, in this case South Korea do not against to USA and start decrease of amount of export energy recourses from Iran, which means South Korea need to other alternative partner. In the same time, it appears of national interests of Uzbekistan where government made project of attract foreign investment for achieving economic growth. From this cooperation both sides satisfy, because national interests of both side are accepted and act to realize on this way. National interests differ in their importance and influence in the international arena. 
According to these characteristics, they are divided into vital (main) and secondary; constant and variable; long-term and conjunctural. Vital and permanent national interests are determined by the most important geopolitical parameters; place and role of this state in the system of interstate relations, its potential, prestige, the ability to defend its sovereignty and guarantee the security of its allies. Each state assesses in its own way the relative importance of each of the objectives pursued by it, the ability to realize them depends on many factors, but the arsenal of means of ensuring interests has remained unchanged for centuries: political, economic, diplomatic, military. The main component of national interest is the imperative of the state's self-preservation, which is complemented by security issues from external threats, protection of the state's economic and political positions in relations with other states, and expansion of state influence in world politics.

In realistic approach rationalism plays main role with national interest norms. Rationalism is used in decision theory. Decision making theory emerged at the junction of several sciences: mathematics, mathematical economics, sociology and psychology. The theory of rational choice has come to political science from the economy. It proceeds from the fact that in the sphere of power and decision-making about common goods, a person behaves rationally, as well as in economic life. The one who makes the decision pursues a certain goal or goals. If there are several goals, they are structured, based on their importance or preferences of the subject. Information on the current situation and how the situation affects the subject's goals is accessible to him and known. The state considers possible alternatives to achieving a goal or goals, evaluating them in terms of a combination of price and win, and likelihood of success. Then he chooses the best of the alternatives in terms of balance of price and win, as well as the probability of success.

\section{Liberalism in international relations}

In fact, this school is opposition of political realism, and not only in terms of explaining the world order, but also in understanding what it should be like. Achieving the maximum possible freedom of man is the main goal of liberalism, but it can be achieved only in the absence of war and the prerequisites for its emergence. And since conflicts and wars are an integral part of the existing system in which sovereign states seek to maximize power, the circumstances necessary for the realization of human freedom can arise only on the condition of "governance or transcending the policy principle from the position of strength" (governance or transcendence of power politics). This argument is supported by four main provisions:

- Rational and ethical point view, international cooperation helps to international regulation;

- For effective managing of international relations, the rational policy is necessary norm;

- International organizations help to contribute to the spread of peace and stability by pacifying stronger states toward the creation of international norms and new rules for the conduct of multilateral policies; in addition, they have the necessary tools to prevent or manage interstate conflicts;

- After making gradual reforms or domestication of international relations where means legal state, universal human 
rights, the position of power is not seen as primary tool for maintaining interstate order.

Liberals believe to power of human mind and interstate wars is not right or rational way to solve problems. To achieve direct result or resolution or solve differ kinds of problems, one group of liberals offer idea of civil society and other group refer mercantilist idea, it's about concept of free trade. Scholars conclude that in order to prevent wars firstly it is necessary reorganize and do reforms inside states and after that it can be possible to enter international relations. From these ideas comes the core concepts of liberalism and there we have mention about Immanuel Kant, Jeremy Bentham and Adam Smith. Immanuel Kant and Jeremy Bentham believed that if governments are override to the will of public opinion, wars would be avoided. However, they emphasized that reforms inside states and appearing of civil society and same time they pointed out the importance of international law where should be "cosmopolitan rights" directed guaranteeing peace by defining rights and responsibilities of citizens and states that is established refuse of war policy by states. From these cosmopolitan ideas comes such modern order of collective security, states become more interdependent, they strengthen democracy where are peace and stability.

The key moment is a social contract, according to which laws are issued with the consent of society for its good and protection of social norms, and every citizen obeys these laws. Particular emphasis is placed on the rule of law, in particular, liberalism proceeds from the assumption that the state has sufficient power to provide it. Modern political liberalism also includes the condition of universal suffrage, regardless of gender, race or property status; the most preferred system is considered. Although states are recognized as the main participants in international relations under a liberal approach, they are by no means the only players in this field: the interaction of states, according to the liberals, must necessarily be regulated by intergovernmental organizations and international regimes. Along with them, non-governmental organizations are also called upon to play an active role in human rights, environmental, transnational corporations and others. According to the liberal model, states are oriented not only to maximizing profits, but also to mutually beneficial cooperation. The force factor in this model gives way to other, more effective means of influencing economic and legal levers and mechanisms.

To understand and analyze the modern international relations by approach of liberalism there should be some work of this approach. One of the such kind of work is the theory of complex interdependence. Robert $O$. Keohane and Joseph S. Nye, JR on their book "Power and Interdependence" they argued about complex interdependence and this is the most challenging idea against to realism. In a complex interdependence, they try to find differences between realism and complex interdependence where complex interdependence is closer to reality than realism. For realists three assumptions are most important: the status of state, in international relations state is only and dominant actor; power is effective instrument of politics; hierarchy issue, it relates to military security where means that powerful states by military security outstanding the low states of economic and social affairs. Include these 
assumptions complex interdependence gives three challenging characteristics. Where explains with current and modern examples.

First one is multiple channels, it consists of different kind of informal ties. They are interstate, trans governmental, transnational relations. Interstate relations is classic and normal channels in international relations especially assumed by realists. Trans governmental relations include informal ties between nongovernmental elites, it would be face to face, by telecommunications. Transnational relations ties between transnational organizations such as multinational banks, corporations. Transnational organizations influence to domestic and interstate relations and active participation of international organizations in foreign affairs are becoming normal condition and these actions do not controlled by governments. Their activities not only consist of pursuing interests but also, they make transmission belts. Domestic affairs are becoming broadening and different kind of corporations, banks, trade unions are making decisions which related to set up relations with other foreign partners without government. It may include such kind of activities economic, trade, environmental regulation, technology sphere and so on. Under complex interdependence, there questions will appear: by exercising policy and relations among trans governmental, transnational level, they do which self and which interest? Certain government agencies follow its own interests under the national interest.

The second is absence of hierarchy among issues, it means interstate relations include different kind of issues and problems do not solve by military or politics. Many issues should be considered various government agencies, departments and different levels. For instance, departments of agriculture of two or other countries will consider among water problem or environment issues other and other different kind of issues should consider certain organizations or institutions. With the complex interdependence can affect to the international and domestic problems originated by economic growth and growing interdependence. Separate domestic parts will politicize issues and push more problems into interstate agenda. Also, agendas is affected by the distribution of force resources with the different kind of issues.

Third one is minor role of military force, the role of military force is emphasized by political scientists and state with higher military forces is powerful. Especially, it relates to security issues and it will be guarantee of survival. However, in modern industrialized, democratic, countries fear of attacks by other states declined and almost not existed. Thus, military power become less important and ineffective instrument in international policy. Nowadays, more important issues appeared such as economic, trade, environmental, social, educational relations. In this case, military force is unnecessary tool to resolve among these issues and it considered certain ways of resolving and regulated by governmental and nongovernmental, transnational level. Military force will be necessary in a protect and defence situation, in other conditions it will be ineffective. It means that scale and mean of military force as political instrument become shrinker.

So, there was detected that scholars by put in challenge realism and giving theory of complex interdependence, there are big differences. 
The goals of states are differentiated by issue area and transitional and trans governmental actors are playing most important role which pursue their goals. For realist approach military power is dominant goal. Active participation of interdependence, international organizations and transnational actors will be major instruments. Here state instruments in exercising foreign policy put in same level with multiple channels. But contrast this realist approach put state in dominant place and other instruments may be used. agenda plays an important role in changing, distribution of power clearly means distribution of power resources with issue areas, linkages from other issues and polarization, international regimes and its status, the actors' importance of transnational relations. On the other hand, realist thinking argues that agenda is influenced by balance of power, security and in high politics simultaneously affect to other agendas. There is also difference among linkages, one side approve that linkage will diminish the differences in outcomes in problem areas and strengthen the international hierarchy and complex interdependence pointed out in a strong states power will be ineffective and linkages will be more difficult. In weak states linkages by international organizations will reduce rather than reinforce hierarchy. And final aspect is role of international organizations, realism approach says that role is minor and limited by state force, instead of this military force is in dominant place. But contrast this under complex interdependence, international organizations can act as actor of international relations and set agendas, make decisions and act for political actions by weak states. International organizations able to choose its forum for an issue and mobilize votes and it will be an important for policy.

Theory of complex interdependence eventually changed the view of international relations and add new approach. It may be appropriate to modern international area and to explain relations of countries by this theory will be more clearly. For instance, relations of South Korea and Uzbekistan by three conditions which are absence of force, lack of hierarchy and contact of multiple channels. From these criteria we can see that there is no role of power or force between two countries relations, the most accent has made in different kind of cooperation between them which is appropriate with multiple channels are playing significant role in this condition. If we take lack of hierarchy, there is same with condition of absence of force.

\section{CONCLUSION}

In this work we discussed about foreign policy and realism, liberalism approaches. In foreign policy relations two countries are so complicated and nature, ways their relations should explained by proper theory of international relations. That is why realism and liberalism approaches are chosen to define this task. Theory of realism can describe relations of South Korea and Uzbekistan, but in some aspects, it is not fit for it. Because values for realism such as role of power, force and others cannot be suitable for describing nature of relations between South Korea and Uzbekistan. Between them there is no power or demand of using military forces. On the other hand, most common and well explaining approach is liberalism. From these analyses we come to conclusion that most suitable approach to describe and analyse relations of South Korea and Uzbekistan is liberalism, 
clearly theory of complex interdependence. The concept of complex interdependence defined by three conditions absence of hierarchy, force and multiple channels. Because in relations of South Korea and Uzbekistan we can notice that multiple relations, absence of force and hierarchy. To clarifying this theory with our case study we can give some examples for it. Uzbek-South Korean relations have acquired a mature, fully thought-out and mutually beneficial character at the interstate and intergovernmental levels, in terms of cooperation between economic and commercial structures, companies and firms, including in the humanitarian sphere, and meet the vital interests of the peoples of our countries. The commonality of political and economic goals, the proximity of cultures and ways of life, the relentless pursuit of achieving their goals - these qualities will always bring Uzbek and Korean peoples closer, strengthen friendship and cooperation.

According to analyses of theoretical aspects of work, we can give some proposals for case study part of our work. For more effective development of bilateral and multilateral relations between the Republic of Korea and Uzbekistan:

1. In order to more effectively coordinate activities in the framework of bilateral and multilateral cooperation, the establishment of a regular format of meetings between interested agencies, enterprises and organizations can be considered.

2. In order to further develop friendly mutually beneficial relations between states, it is possible to work out cooperation projects in the field of science, culture and education.

\section{REFERENCES}

1. Robert O. Keohane and Joseph S. Nye, JR. Power and Interdependence. Princeton University press, 2012.

2. Williams, David. International development and global politics: history, theory and practice. Routledge, 2012.

3. John Baylis, Steve Smith, Patricia Owens. The globalization of world politics: an introduction to international relations. Oxford University Press, 2014.

4. Дугин А. Г. Международные отношения (парадигмы, теории, социология): Учебное пособие для вузов. - 2-е изд. М.: Академический проект, 2014. - 431 c- (Gaudeamus)

5. "Uzbekistan - South Korea: New stage of the strategic partnership", report UzA, November, 2017. http://uza.uz/en/politics/uzbekistan-southkorea-new-stage-of-the-strategicpartnershi-23-11-2017

6. Сотрудничество с общественными организациями Республики Корея // http://gulnarakarimova.com/ru/pages/mej dunarodnoe-sotrudnichestvo-koreya/

7. "Korea, Uzbekistan Enter New Partnership Era," Korea Times, August 30, 2012.

8. “Отношения между Республикой Узбекистан и Республикой Корея подняты на уровень особого стратегического партнерства", report UzA, April 20, 2019. https://uza.uz/ru/posts/otnosheniyamezhdu-respublikoy-uzbekistan-irespublikoy-kore-20-04-2019

9. "Uzbekistan - South Korea: New stage of the strategic partnership", report UzA, November, 2017. http://uza.uz/en/politics/uzbekistan-south- 
The American Journal of Political Science Law and Criminology (ISSN - 2693-0803)

Published: April 30, 2021 | Pages: 213-222

Doi: https://doi.org/10.37547/tajpslc/Volume03Issue04-33

korea-new-stage-of-the-strategic-

partnershi-23-11-2017

10. Balbina Hwang. A new horizon in south

Korea-Central Asia relations: the ROK joins

the "Great Game", Korea Compass,

December 2012.

11. Matteo Fumagalli. South Korea's engagement in Central Asia. 2012. https://www.researchgate.net/publication /272747874_South_Korea\%27s_engageme nt_in_Central_Asia 